\title{
PELATIHAN KERAJINAN BAMBU DI DESA \\ TUMALUNTUNG KECAMATAN TARERAN
}

\author{
Ruly Rantng
}

\section{ABSTRAK}

Tugas utama perguruan tinggi adalah melaksanakan Tridharma, salah satu diantaranya adalah Pengabdian pada Pasyarakat, dengan melibatkan seluruh komponen Civitas Akademik. Hal ini dilaksanakan dalam usaha memberdayakan masyarakat melalui pelatihan dan penyuluhan. Partisipasi perguruan tinggi dengan program kemitraan yang memberikan tenaga dan kosep-ponsep yang membangun dan memajukan perekonomian, salah satunya menciptakan lapangan kerja dalam bentuk ekonomi kreatif melalui kelompokkelompok pengrajin. Program kemitraan yang dilaksanakan ini berlokasi di Desa Tumaluntung Kecamatan Tareran Kabupaten Minahasa Selatan. Sedangkan program ini difokuskan pada kelompok pengrajin dengan memodifikasi kerajinan nyiru menjadi karya seni yang lebih menarik, modis dan berdaya jual tinggi.

Keywords: Bambu, modis, desain 


\section{PENDAHULUAN}

Usaha pemerintah menuju perubahan untuk meningkatkan kesejahteraan masyarakat bukan dengan serta-merta menyalurkan dana dalam memenuhi kepentingan belanja kebutuhan keluarga, akan tetapi melalui strategi program yang visioner. Hal ini terkait dengan aktivitas masyarakat produktif yang dapat dikembangkan ke arah meluasnya lapangan kerja yang pada dasarnya harus membutuhkan tenaga-tenaga profesional dalam hal kepakaran.

Departemen Pendidikan Tinggi yang didalamnya terdapat DIRJEN Pendidikan Tinggi yang berorientasi pada Tridarma Perguruan Tinggi adalah salah satu lembaga tinggi negara yang telah turut berperan dalam percepatan terwujudnya suatu masyarakat yang berbudaya, maju, berkualitas sejahtera dan berdaya saing. Bentuk kepedulian social yang diperankan oleh Dirjen Dikti adalah menyisihkan dana pengabdian pada masyarakat bekerja sama dengan perguruan tinggi pada penerapan Ilmu Pengtahuan, Teknologi dan Seni (IPTEKS) dilihat dari karakter dan permasalahan yang dihadapi dalam menjawab kebutuhan masyarakat.

Untuk menyalurkan sejumlah dana yang disiapkan oleh pemerintah melalui Dirjen Dikti dapat dipilih dari beberapa skema, salah satu adalah skema Pengabdian kepada masyarakat diperuntukan bagi upaya pemberdayaan masyarakat melalui pembekalan Ilmu Pengetahuan, teknologi dan Seni yang nantinya dapat meningkatkan ketrampilan dan profesionalitas pekerjaan yang ditekuni secara tradisional. Dapat diperuntukan bagi pemberdayaan usaha kelompok-kelompok pengrajin lebih professional dalam meningkatkan kualitas produk pada persaingannya dipasar global yang diapresiasi untuk meningkatkan taraf taraf hidup masyarakat.

Diharapkan program kelompok pengrajin nyiru di Desa Tumaluntung Kecamatan Tareran Kabupaten Minahasa Selatan yang menjadi sasaran pengabdian masyarakat ini akan terjadi perubahan dalam perbaikan ekonomi. Walaupun kelompok pengrajin nyiru ini tidak berada pada satu tempat karena mereka bekerja di masing-masing rumah tetapi krlompok pengrajin yang dibentuk dan diasuh langsung oleh Ibu Linda Rumondor akan mengalami kemajuan. Program pelatihan ini kehadirannya akan benar-benar membantu dalam berkarya dengan hasil yang inovatif.
Kelompok pengrajin yang dibentuk berjumlah 16 orang semuanya perempuan. Ini dikarenakan sejak dulu anak perempuan sudah dilatih oleh ibu dengan menganyam karena istri yang tidak ikut suami ke kebun mereka bekerja di rumah membuat nyiru (dalam bahasa lokal "sosiru"). Kelompok pengrajin ini yang berijazah SMA sederajat 11 orang, sedangkan yang berijazah Sekolah Menengah Pertama berjumlah 5 orang. Permasalahan yang dihadapi di lapangan bahwa pada umumnya pengrajin nyiru di desa ini masih berprofesi ganda (berdagang, berkebun, tukang dll), sehingga perhatian dalam pekeijaan sering terbagi atau belum sepenuhnya terfokus pada pekerjaan kerajinan. Kendala utama adalah modal usaha dan pemasaran produk.

Jika ditinjau dari masa ke masa pengrajin nyiru di desa Tumaluntung ini tidak pernah berubah, hasilnya masih sangat tradisional. Karya kerajinan hanya terbatas pada aplite art (seni pakai), digunakan intuk kepentingan dapur seperti menampi beras. Di bawah ini dapat dilihat proses pembuatannya :

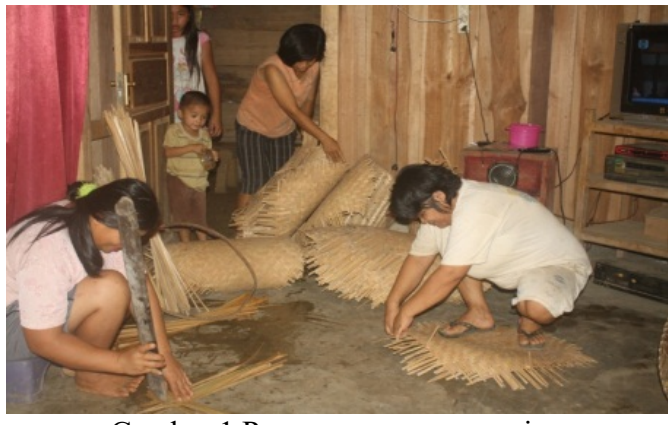

Gambar 1 Proses menganyam nyiru

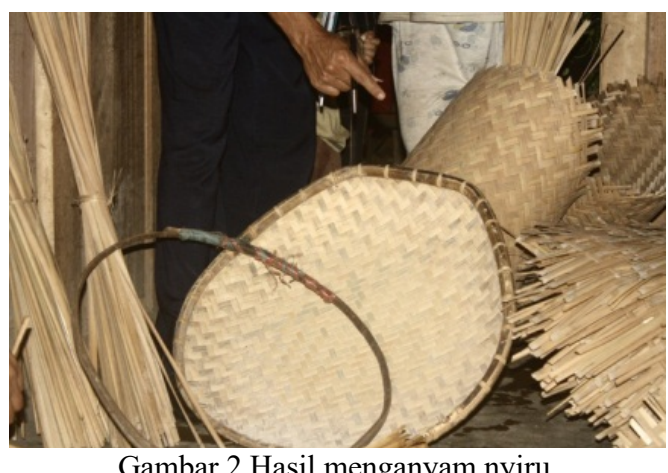

Hal ini dikarenakan belum ada sentuan desain inovatif yang memotivasi mereka untuk berkreasi dengan media bambu ini. Dengan demikian diharapkan pelatihan yang akan dilaksanakan ini akan merubah pola pikir para pengrajin untuk tidak lagi membatasi karya dengan nyiru akan tetapi menghasilkan karya-karya yang inovasi dengan daya jual yang menjanjikan.

\section{METODE}


Kegiatan pelatihan ini dilaksanakan dengan tahapan yang sudah diatur sebagai berikut:

A. Materi, metode dan teknik pelatihan.

1. Materi pelatihan dapat dibagi atas beberapa bagian yaitu :

a. Penjelasan tentang seni kerajinan

b. Penjelasan tentang kewirausahaan

c. Penjelasan tentang pengelolaan pekerjaan (manajemen proyek)

d. Pembuatan desain

2. Metode dan teknik pelatihan

a. Bagian penjelasan tentang fungsi seni kerajinan, pengenalan alan dan bahan menggunakan metode ceramah dan tanya jawab

b. Pembuatan desain enggunakan metode demonstrasi

c. Praktek pembuatan seni kerajinan mnggunakan teknik bimbingan langsung

B. Media dan bahan pelatihan

Media dan bahan yang digunakan dalam pelatihan adalah :

- Bambu

- Pisau / parang

- Pisau cuter

- Lem / perekat

- Vernis

- Kertas amplas

- Kertas/buku gambar

- Pensil

C. Evaluasi

Evaluasi dilakukan dua kali yaitu :

1. Pada saat pembuatan desain, apakah desain dapat digunakan atau tidak

2. Dilakukan pada akhir pelatihan

Langkah-langkah yang ditempuh sebagai berikut :

a. Hasil observasi diketahui fokus permasalahan yang paling urgen untuk dilaksanakan program ini yaitu pelatihan desain produk, teknologi industri dan manajemen pemasaran

b. Menetapkan/ menentukan nama-nama anggota kelompok mitra pengrajin yang ikut serta dalam pelatihan.

c. Menetapkan jadwal pelaksanaan program pelatihan menurut kesepakatan tim pelaksana dan kelompok mitra binaan

d. Realisasi pelaksanaan pelatihan sesuai materi pelatihan yang disepakati menurut jadwal.

\section{KELAYAKAN PERGURUAN TINGGI}

UNIMA adalah salah satu perguruan tinggi yang mengelola lembaga pendidikan tenaga kependidikan (LPTK), sangat erat dengan pendidikan kepelatihan dan wirausaha di masyarakat. Dengan adanya Lembaga Pengabdian pada Masyarakat (LPM) menjadi bukti bahwa UNIMA sangat berhubungan langsung dengan kegiatan-kegiatan kemasyarakatan dalam menunjang program pemerintah.

Melalui lembaga ini maka Unima dapat memberikan sumbangan terhadap peningkatan sumber daya manusia baik dikalangan tenaga dosen, pegawai maupun mahasiswa terlebih terhadap masyarakat guna meningkatkan keahlian dalam rangka pengembangan keahlian dibidang seni maupun keterampilan dalam usaha ekonomi kreatif. UNIMA memiliki banyak tenaga professional yang siap berkarya demi keterpanggilannya sebagai pendidik, bahkan tenaga-tenaga dosen di Jurusan Pendidikan Seni Rupa dan Kerajinan untuk mengembangkan keahlian serta ilmu yang ada untuk diterapkan kepada masyarakat dalam kategori usia kreatif yang diharapkan agar di kemudian hari mereka telah memiliki bekal keterampilan/kecakapan hidup (life skill) dibidang seni, dan mampu mengembangkan diri melalui keterampilan berkarya.

Adapun pelatihan yang akan dilaksanakan melibatkan tenaga-tenaga professional dengan kepakarannya di bidang kesenirupaan sehingga dapat menjawab persoalan berbagai kebutuhan mitra seperti:

a. Bidang Kesenirupaan/ Desain Produk

b. Bidang Industri Kerajinan Tangan/ Handy Craft

c. Bidang Manajemen dan Pemasaran/ Kewirausahaan

Kompetensi Tim Pelaksana berdasarkan kualifikasi akademik baik ketua tim maupun anggota sangat sesuai dengan keahlian yang digeluti seperti gambaran berikut:

\section{HASIL PELATIHAN DAN PEMBAHASAN Hasil Pelatihan}

Dua kelompok peserta pelatihan diambil dari masyarakat yang boleh memberi waktu untuk coba berkreasi dengan media bambu. Peserta pelatihan diberi kebebasan berekspresi membuat gambar rencana, dengan demikian pelaksanaan kegiatan ini para peserta sangat merespons dilihat dari keseriusan peserta mengikutinya sehingga evaluasi pada bulan pertama hasilnya memuaskan, para peserta begitu tekun walaupun karya-karya yang mereka hasilkan belum dapat dikategorikan sebagai karya yang siap jual, seperti kasil karya di bawah ini : 


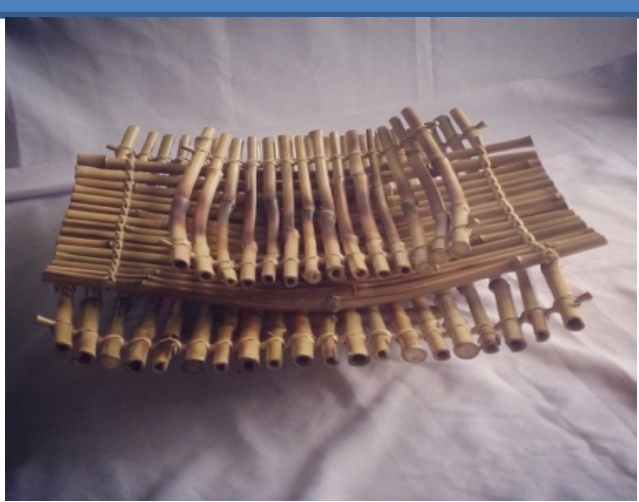

Gambar 6. Tempat buah dari ranting bambu

Pada hakekatnya untuk semua jenis ranting bambu dapat digunakan untuk berkreasi, tetapi dalam hal ini kedua kelompok peserta pelatihan hanya menggunakan jenis ranting bambu kuning sebab bambu ini banyak terdapat di desa tempat pelaksanaan pelatihan. Yang menarik adalah banyak anak-anak yang ikut dalam pelatihan ini walaupun mereka hanya mengambil waktu setelah pulang dari sekolah. Para instuktur sangat merasa bangga dengan kehadiran anak-anak sekolah karena kepada merekalah semua akan diserahkan. Apa yang dilakukan orang dewasa dan orang tua itulah yang akan tertular pada generasi mendatang. Anak-anak senang melakukan eksperimen apalagi orientasinya pada hasil karya seni, walaupun mereka belum pernah berpikir tentang nilai ekonomi akan tetapi setidaknya mereka telah mengenal bagaimana limbah setelah diolah menjadi barang bermakna dan bernilai jual.

\section{Pembahasan Hasil Pelatihan}

Hasil kerja membuat seni kerajinan dari ranting bambu pada dua kelompok sebagai peserta pelatihan memang masih sangat sederhana, akan tetapi hasil ini adalah pekerjaan maksimal pada tahap awal. Yang terutama masyarakat boleh belajar bagaimana memanfaatkan limbah ranting bambu menjadi karya seni yang indah setelah mendapat pelatihan dan bimbingan secara langsung.

Dari hasil yang diperoleh pada pelatihan ini dapat diapresiasi positif terhadap respon dan antusias peserta pelatihan yang tekun bekerja, bahkan beberapa masyarakat yang turut mengambil bagian dalam pelatihan ini termasuk anak-anak sangat merasa tertarik dengan apa yang mereka buat dalam hal pemanfaatan ranting bambu yang berlimpah di desa.

Pemerintah setempat, masyarakat dan para peserta sangat mengharapkan kelanjutan dari kegiatan ini karena mereka telah merasakan secara langsung kegunaan dari kegiatan ini dengan pengembangan desain yang lebih modis dan berharga jual.

\section{KESIMPULAN}

Kegiatan pelatihan membuat kerajinan dari ranting bambu pada masyarakat Desa Tumaluntung Kec. Tareran yang diwakili oleh dua kelompok usia produktif terlaksana dengan baik dilihat dari respon pemerintah dan masyarakat serta keseriusan para peserta yang mengikuti pelatihan, dan dapat menghasilkan karya yang berfungsi sebagai karya seni pakai.

Masyarakat usia produktif adalah warga masyarakat yang terbilang masih mampu berkreasi yang perlu pembinaan agar mereka dapat melaksanakan hal yang positif dan membentuk pribadi yang ulet, kreatif dan inovatif.

Ranting bambu adalah bahan yang mudah didapat karena wilayah pertanian desa Tumaluntung sebagian besar ditanami pohon bambu, karena tanaman ini sering digunakan oleh masyarakat untuk berbagai keperluan.

\section{DAFTAR PUSTAKA}

Berlian, Nur V.A., 1995. Jenis dan prospek bisnis bambu. PT Penebar Swadaya; Jakarta

DP2M DITJEN DIKTI, Panduan Pelaksanaan Penelitian Dan Pengabdian Masyarakat Di Perguruan Tinggi Edisi IX Tahun 2013, KEMENDIKBUD, Jakarta

Gunarto Murtihadi, 1982, Dasar-Dasar Desain (Untuk SMIK), Depdikbud, Jakarta

Gustami, SP, 1980. Nukilan Seni Ornamen Indonesia. Sekolah Tinggi Seni Rupa Indonesia, Yokyakarta

Gustami S. P, 2007. Butir-Butir Mutiara Estetika Timur (Ide Desain Penciptaan Seni Kriya Indonesia), Prasista Jogyakarta

Kalangi, N. S., 1995. Kebudayaan Minahasa, dalam Kuntjaraningrat., ed. Manusia dan Kebudayaan Indonesia.Jakarta : Djambatan.

Sachari, Agus. Sari Design dan Teknologi. Bandung : Pustaka, 2003

Umar, Kayam, Kreativitas Dalam Seni dan Masyarakat Suatu Dimensi Proses Pembentukan Budaya dalam Masyarakat, dalam Analisis Kebudayaan, Departemen Pendidikan dan Kebudayaan, Jakarta. 1981/1982. 